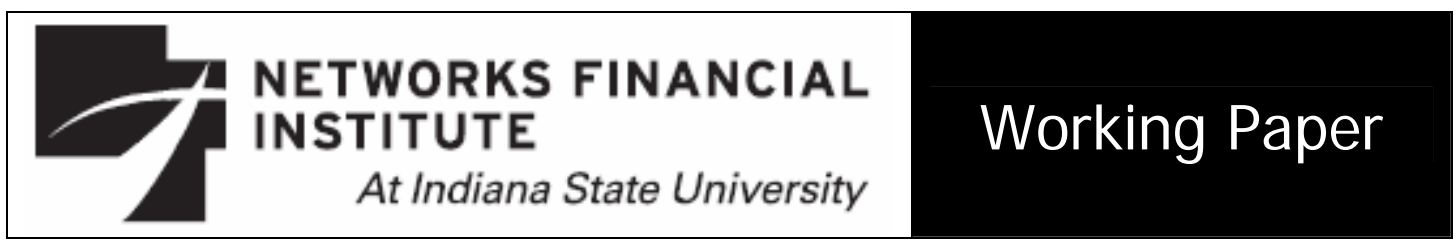

2006-WP-01

April 2006

\title{
Repayment Performance in Group Lending Programs: A Survey
}

\author{
Joel M. Guttman
}

Abstract: This paper surveys the theoretical and empirical literature on group lending programs in developing countries, with a focus on the determinants of repayment performance.

About the Author: Joel M. Guttman is a Senior Fellow at Networks Financial Institute. Guttman is currently serving as an associate professor in the department of economics in Bar-Ilan University. He has also served as a visiting professor at the University of Chicago, Brown University and the Helsinki School of Economics. His research areas include evolution of trust and cooperation, economic growth and conflict (internal and external), public economics, applied game theory, and defense economics. He has published numerous articles in scholarly journals including American Economic Review, Journal of Political Economy, Journal of Public Economics, and Economic Journal. He received his Ph.D. in economics from the University of Chicago.

The views expressed are those of the individual author and do not necessarily reflect official positions of Networks Financial Institute. Please address questions regarding content to J oel M. Guttman at guttman@mail.biu.ac.il. Any errors or omissions are the responsibility of the author.

NFI working papers and other publications are available on NFI's website (www.networksfinancialinstitute.org). Click "Research" and then "Publications/Papers." 


\title{
Repayment Performance in Group Lending Programs: A Survey
}

\author{
Joel M. Guttman
}

\section{Introduction}

Individuals and organizations engaged in promoting economic development are concerned not only with generating economic growth (enlarging the "pie" in developing countries) but also with ensuring that the beneficiaries of growth include the poor of these countries. Productive investments require capital, and the poor typically have difficulty in demonstrating their creditworthiness to financial institutions. Thus it is generally believed that financing economic development requires a system of making loans to the poorest strata of developing economies.

Until the 1970s, this goal generally was not achieved. In Bangladesh, for example, the 1970s and 1980s saw an effort by the government to extend subsidized credit, through the existing banking system, to the rural sector. (Previously loans were almost exclusively made to the urban sector.) The provision of government-subsidized funds lent itself to political pressures being applied on program managers to favor big borrowers who had political patronage. The favoring of big borrowers was also motivated by incentives to save transactions costs, by servicing a small number of large borrowers rather than a large number of small borrowers. The inability to use the legal system to foreclose and liquidate collateral in the rural sector (World Bank, 1994) decreased borrowers' cost of default. Problems of high default rates were exacerbated by frequent announcements of loan amnesty and interest remissions, themselves often responses to political pressures. The recovery rate on rural loans by traditional commercial banks, not surprisingly, plummeted from a poor 51.6 percent in $1980-81$ to a dismal 18.8 percent in $1988-89 .^{1}$

The extreme poverty of Bangladesh in the mid-1970s induced economist Muhammed Yunus to look for an alternative method of providing small loans to the poor. As Yunus describes it,

\footnotetext{
${ }^{1}$ The recovery rate is defined as the "percent of target loans recovered relative to total target loans, including principal and interest." The source of this definition, as well as the description of events in Bangladesh, is Sharma and Zeller (1997).
} 
Bangladesh had a terrible famine in 1974. I was teaching economics in a Bangladesh university at that time. You can guess how difficult it is to teach the elegant theories of economics when people are dying of hunger all around you. Those theories appeared like cruel jokes. I became a drop-out from formal economics. I wanted to learn economics from the poor in the village next door to the university campus. (Yunus 1995, quoted in Morduch, 1999)

This led Yunus to lend small sums to local villagers from his own pocket, in order to enable them to buy materials for projects like making pots and weaving bamboo stools. In the early 1980s, Yunus founded the Grameen Bank, which became a model for similar institutions in many developing countries, as well as experiments even in developed countries such as the United States.

The basic idea of the Grameen Bank and similar microfinance institutions is to provide small loans to the poor with minimum transactions costs and maximum probability of repayment, by lending to small groups of borrowers who become jointly liable for each other's debts to the bank (the principle of group liability). Additional features of the loans made by these institutions are: (a) loans are repaid in small, periodic payments rather than in one lump sum, and (b) default by the group can trigger the inability of the group to obtain loans in the future from the bank. These methods utilize the informational and enforcement advantages that groups of borrowers have in comparison to the corresponding capabilities of conventional banks.

This paper surveys the theoretical and empirical literature that explains and assesses the success of these group lending institutions. Section 2 discusses theoretical models that have been developed to explain the advantages of group lending in comparison to individual lending in the context of developing economies. Section 3 surveys the empirical studies that have been conducted to identify the factors that influence the success of group lending techniques. Section 4 concludes.

\section{Theoretical Models}

Theoretical work on repayment incentives in group lending programs has been motivated by the widespread observation that such programs have been characterized by very high repayment rates - on the order of 95 percent in many cases. The success of group lending schemes in terms of repayment rates raises the question as to what aspects of such schemes are likely to be the causes of such repayment performance. In particular, I noted above that group liability is only one aspect of such programs; other aspects include the institution of small, periodic repayment schedules and the refusal to provide loans in the future if the group defaults.

Ghatak and Guinnane (1999) identify four tasks that financial institutions, in general, must accomplish in order to lend efficiently:

1. Ascertaining the level of risk of default of the borrower (the problem of adverse selection) 
2. Ensuring that the borrower will use his or her loan in a prudent manner, so as to maximize the probability of repayment (the problem of moral hazard)

3. Monitoring the degree of success of the borrower's project, so as to determine whether the borrower can repay the loan in the case that the borrower claims inability to repay (the auditing problem) ${ }^{2}$

4. Enforcing repayment of the loan when the borrower (strategically) attempts to default (the enforcement problem)

Tasks 1 and 2 deal with what the lender can do ex ante-before lendingto ensure repayment. Tasks 3 and 4 deal with the ex post problem of ensuring that the borrower repays if he is able to repay. Task 4 , however, is unlike the other three tasks in that it has nothing to do with asymmetric information. Even in a world of perfect information, the problem of enforcing contractual obligations would exist. In such a world, tasks 1, 2 and 3 would be absent, since these three tasks assume that the lender lacks information either about the lender's type or about the actions that he takes using the loan that he has received.

In conventional banking, these tasks correspond to problems that the bank must solve. In group lending, the lending institution shifts one or more of these tasks to the group receiving the loan, rather than trying to accomplish these tasks on its own. The advantage of doing so, in the context of the developing countries in which group lending has usually been instituted, lies in (a) the relatively large amount of information that individuals in such societies possess of each other's behavior and character traits, given that these people tend to live in close proximity to each other and tend to be geographically immobile, and (b) the fact that poor people have very little collateral that can be used as to enforce repayment, coupled with the legal difficulties faced by lenders who try to repossess collateral in such societies, particularly in rural areas.

Theoretical models of group lending focus on one or more of the tasks listed above, and model how a group can be expected to accomplish these tasks when group members have easier access to the information required to solve these problems (particularly tasks 1-3) and have sanctions available to be used against defaulters that lending institutions do not possess (task 4). In this section, I discuss how these problems have been argued to be solvable by using the group lending method.

\footnotetext{
${ }^{2}$ The present survey will treat this problem as part of the moral hazard problem for two reasons. First, models specifically addressing the auditing problem are generally lacking in the literature [although there is an analysis in Ghatak and Guinnane (1999)]. Second, the auditing problem is conceptually very similar to the moral hazard problem. In both cases, the borrower has private information which he uses to his advantage (and to the disadvantage of the lender) - either information on his effort level or choice of project, or information on the degree of success of the project.
} 


\subsection{Adverse Selection}

The problem of adverse selection derives from the fact that lenders cannot perfectly observe the quality of potential borrowers. Lenders prefer borrowers who will be able to repay (i.e. they will make productive use of the borrowed funds) and are motivated to repay (will not default for opportunistic reasons, when legal enforcement is costly). Given that lenders cannot ascertain the type of the borrower, while borrowers know their own type, a problem of asymmetric information is present. Borrowers will tend to take advantage of this problem, and thus the population of individuals requesting loans will be composed of a disproportionate share of "bad risks." In other words, the population of individuals seeking loans will adversely select low-quality, or risky borrowers.

Ghatak (1999), van Tassell (1999), and Laffont and N'Guessan (2000), following a suggestion made by Stiglitz (1990), have argued that group liability induces borrowers of differing risk levels to "sort themselves" into high- and low-risk groups, enabling at least the partial solution of the adverse selection problem. ${ }^{3}$ This self-sorting relies on the fact that individuals in tightly knit villages of developing countries know each other, and can assess the quality of potential fellow group members much better than can external lending institutions. It should be emphasized that this self-sorting can only occur if the groups receiving loans form themselves, rather than being assembled by the lending institution.

The argument begins by noting that, in general, borrowers would prefer to have "safe" borrowers as fellow group members, since this reduces their risk of having to repay their peers' debts when their peers default. Interestingly, however, risky borrowers will be willing to pay less than safe borrowers to have safe peers in their group. To see why this is true, consider the extreme case of a borrower who knows, for whatever reason, that he has a zero probability of repaying his debt. Such a borrower knows that if his fellow group members also default, this will have no impact on his own wealth, since in any case he will default and therefore declare inability to repay the debts of his peers. In contrast, consider a completely safe borrower who intends to repay her own loan, and also knows with certainty that she will be able to repay. She then will have to repay a part of the debts of her peers if they default. Therefore she will be willing to pay more than the first, low-quality borrower, as a sidepayment to prospective peers, in order to have other safe borrowers as fellow group members.

Let us now state the argument more generally. Given that risky borrowers (by definition) are more likely to default and thus be unable to repay

\footnotetext{
${ }^{3}$ Laffont and N'Guessan (2000) differ from Ghatak (1999) and van Tassel (1999) in that Laffont and N'Guessan (2000, section 4) obtain assortative matching only when sidepayments are not allowed between agents, while Ghatak (1999) and van Tassel (1999) obtain assortative matching even when side-payments are allowed. The difference in results appears to be due to the specific contract that Laffont and N'Guessan (2000, section 4) impose, which, as they note, contrasts with the type of group lending contract used in practice.
} 
their peers' debts, the reduction in risk of having to repay his peers' debts undertaken by a risky borrower, when matched with a safe borrower in the same group, is smaller than the corresponding reduction in risk that would be experienced by a safe borrower. Therefore a safe borrower will be willing to pay more to be matched with another safe borrower than a risky borrower will be willing to pay. Thus risky borrowers will tend to group together, while safe borrowers will tend to group together with other safe borrowers. Note that this self-sorting occurs because of the ability of individuals in the target population to identify each other's riskiness as borrowers - an ability which is presumed to exist owing to the tightly knit nature of villages in developing countries.

Suppose that each borrower takes a loan of one unit of capital, and undertakes to pay $r>1$ (principal plus interest) at the end of the loan time period. Borrowers form a group taking a group loan, in which each borrower undertakes to pay $c$ if a fellow member defaults. ${ }^{4}$ It can be shown that if borrowers sort themselves into groups comprised of either safe or risky borrowers, the lender can offer a loan with high joint liability $c$ and low interest $r$, and another loan with low $c$ and high $r$. The groups composed of safe borrowers will prefer the former contract, and the groups composed of risky borrowers will prefer the latter contract. Under individual liability, this possibility of sorting the borrowers would be absent, since the lender, by assumption, cannot distinguish safe and risky borrowers and additionally has only one instrument, $r$.

In the Appendix, the assortative matching argument is formalized. In addition, a crucial qualification to this argument - which the literature seems to have ignored - is demonstrated. In Section 1, I noted that default is usually punished by withholding future loans from the defaulters. Such penalties are applied only if the group defaults. ${ }^{5}$ It is shown in the Appendix that if $c$ is smaller than the present value of the future loans that the borrower expects to receive as long as the group does not default, then the "assortative matching" argument, outlined above, is turned on its head. Risky borrowers will be willing to pay more, not less, than safe borrowers to have safe borrowers as their fellow group members. Therefore all groups will be mixed.

To understand intuitively this argument against assortative matching, suppose that a group is comprised of only two borrowers, and that both borrowers will repay their debts if their investment projects succeed. The success or failure of each project is assumed to be a dichotomous, random variable,

\footnotetext{
${ }^{4}$ In practice, $c$ can vary with the size of the group and with the size of individual members' loans. We ignore such complications here by assuming a fixed group size and a uniform loan size (one unit of capital).

${ }^{5}$ There appear to be two reasons for this feature of group lending schemes. First, this feature provides incentives for group members to apply pressure on each other to repay, as well to monitor each other in order to ensure that members do not default when they are able to repay (i.e., when their projects succeed). Second, this feature reduces the lender's costs of administering loans. The lender does not need to deal with individual borrowers at all, but only with the group as a whole.
} 
and is independent of the success or failure of the other borrower's project. Assume further that if a borrower's project succeeds, then he will also be willing and able to repay his share of the debts of his fellow group member if her project fails. Then the group will default only if both borrowers' projects fail.

Under the assumptions of the previous paragraph, the probability that the group will default is the product of the probabilities that each of the two borrowers' projects will fail. Each borrower will consider the risk that the group will default, when deciding to "pair up" with another borrower and take a group loan. Given that a risky borrower's own project is relatively likely to fail, the effect on the probability of default by the group (the product of the individual borrowers' probabilities of failure), of having a safe borrower rather than a risky borrower as a fellow group member, will be relatively large for a risky borrower. ${ }^{6}$ Therefore, a risky borrower will value having a safe borrower as a peer more than a safe borrower will value having another safe borrower as a peer, provided that the present value of future loans (that will be unobtainable if the group defaults) is sufficiently large.

In the Appendix it is proved that, under the conditions just specified, there would be no assortative matching if side-payments between prospective group members occur, contrary to the conclusion reached by Ghatak (1999) and van Tassel (1999). ${ }^{7}$ Risky borrowers could profitably "bribe" safe borrowers to match with them rather than with other safe borrowers, since risky borrowers would be willing to pay more to have safe partners than what safe partners would have to be paid to accept them as partners. All groups would be mixed, eliminating the advantage of group lending in terms of adverse selection. Nevertheless, if no side-payments were allowed, it would still be true that safe borrowers would prefer to match with other safe borrowers, leaving the risky borrowers to match between themselves.

It is not clear how likely are such transfer payments between potential group members. As Ghatak and Guinnane (1999) point out, transfers need not be pecuniary: they might be free labor services, for example. What seems

\footnotetext{
${ }^{6}$ A numerical example may clarify this point. Suppose that a risky borrower's project has a probability of failure of 0.3 , and a safe borrower's project has a probability of failure of 0.1 . Then the probability of default of a group composed of a safe and a risky borrower is $0.3 \times 0.1=0.03$, while the probability of failure of a group composed of two risky borrowers is $0.3 \times 0.3=0.09$. Thus the reduction of the probability of default by the group, when a risky borrower has a safe borrower as a partner, as opposed to having another risky borrower as a peer, is $0.09-0.03=0.06$. Now let us make the same calculation for a safe borrower. If he has another safe borrower as a partner, the risk of failure of the group is $0.1 \times 0.1=0.01$. Therefore the reduction of the probability of default by the group, if the safe borrower has another safe borrower as a partner, rather than a risky borrower as a partner, is $0.03-0.01=0.02$. Note that this figure is less than the corresponding risk differential for a risky borrower, which we calculated to be 0.06 .

${ }^{7}$ Laffont and N'Guessan (2000), in their model which assumes that the lender offers an optimal contract that is quite different from the contract used in practice, also obtain that mixing of safe and risky types occurs when side-payments are allowed, yet group lending is still more efficient than individual lending.
} 
clear, however, is that the assortative matching argument stands or falls on the question of whether side-payments are feasible.

\subsection{Moral Hazard}

We now turn to problem 2 listed at the beginning of this section, the problem of moral hazard. Here we assume that borrowers are identical - there are no "safe" and "risky" borrowers - but each borrower can choose to use his or her loan prudently or irresponsibly. Since the lender, by assumption, cannot easily monitor the borrower's use of the loan, the borrower has too small an incentive (from the viewpoint of economic efficiency) to use the loan in a prudent manner. If the borrower decides to invest in a risky project, he shifts part of the risk to the lender, since, in the case of failure of the project, the lender has no recourse to recoup the loss. (We are assuming, as is standard in the literature, that borrowers, being poor, have no collateral that could be repossessed in the case of failure of the project. Thus, in the case of failure, the borrower simply declares his inability to repay.) The borrower who invests in a risky project shifts only part of the risk to the lender, since the lender can still punish default by refusing to make loans to the same borrower in the future. This shifting of risk to the lender is an externality, and like all externalities, leads to market failure.

It is important to note that group liability by itself, i.e., without assuming any informational advantages of other borrowers in the same group, cannot solve this problem. In fact, group liability alone would make the problem worse. To see why this is so, suppose again that there are two borrowers in the group, A and B. If borrower A chooses a risky project, he shifts part of the risk to borrower B, because if borrower A defaults and borrower B does not, then borrower B is liable for A's loan as well. Knowing that borrower A therefore has an incentive to choose a risky project, borrower B has an incentive to choose a risky project as well, since (if her project fails) she escapes her liability for borrower A's loan as well as her own loan.

In order to explain how group lending can solve the moral hazard problem, we must assume that borrowers in the same group can monitor each others' use of their loans at lower cost than the cost to the lender of such monitoring. By living in close proximity to each other, borrowers in villages in developing countries can observe how their neighbors use loans. It then becomes reasonable to expect that the moral hazard problem will be less severe in the context of group lending than it would be with individual lending. Each borrower has an incentive to monitor his fellow group members, since he is liable for their debts as well as his own.

It is assumed that borrowers can easily impose sanctions on fellow group members who are known to have defaulted because they used their loans irresponsibly. Such sanctions include social ostracism, as well as more severe measures such as seizing the delinquent borrowers' property or even destroying such property. Montgomery et al. (1996) note cases in Bangladesh in which defaulters' livestock or household goods were seized by angry group members. 
In one case, they report, the house of a woman who defaulted was torn down.

Stiglitz (1990) was perhaps the first to develop the notion of borrowers' monitoring each other in the specific context of group lending. Stiglitz assumed, however, that group members can make an enforceable contract to choose specified projects, thus automatically solving the moral hazard problem. This assumption is quite unrealistic, since such contracts would be hard to enforce in developing countries: court costs are high, and resorting to outside arbitration may conflict with internal norms of the village.

An alternative, more realistic approach would model the group members' decisions in the context of a non-cooperative game. In the first stage of the game, members would choose whether or not to monitor their fellow members. In the second stage, members decide whether to choose more or less risky projects, in the knowledge of whether they are being monitored. To illustrate, I use a formulation that follows that of Chowdhury (2003) in its broad outlines but differs in some important respects. Suppose, as before, that there are two borrowers in the group, borrower 1 and borrower 2. Each borrower $i$ can choose between two projects. Project 1 provides an return $H$ that can be observed by the lender, while Project 2 yields no observable income, yet provides a return $b$ to the borrower which the lender cannot observe. In other words, Project 1 is observed by the lender to be a success, while Project 2 is observed to be a failure. The projects require an initial investment of one unit of capital, provided by the lender, and the borrower undertakes to repay $r>1$ if the project "succeeds" (if the project "fails" - i.e., if the borrower chooses Project 2 - the borrower has no observed income with which to repay the loan). The lender lends the unit of capital on the understanding that the borrower will invest in Project 1 . The interest rate, $r-1$, is exogenous to the model. In order for Project 1 to be profitable, we assume $H>r$. Moreover, we assume that the borrower (if she is not monitored) prefers Project 2 to Project 1, i.e., there is a moral hazard problem, which implies $b>H-r$. If she is not monitored, the borrower simply invests in Project 2 and then announces that the project (understood by the lender to be Project 1) failed.

While the lender cannot observe which project was chosen by the borrowers, each borrower can monitor his partner at a cost $m$. Monitoring enables the monitored borrower's project choice to be observed by the peer doing the monitoring. The borrowers simultaneously decide whether to monitor before their (simultaneous) investment decisions, and the borrowers know whether they are being monitored when they choose their investment projects. If borrower $i$ 's project "succeeds" (i.e., he chose Project 1) and borrower $j$ 's project "fails" (i.e., she chose Project 2), then borrower $i$ must pay $c$ to the lender. Moreover, if borrower $i$ monitored borrower $j$ and found that borrower $j$ cheated by choosing Project 2, then borrower $i$ punishes borrower $j$ by applying social sanctions that are valued at $-S$. We assume that $b-S<H-r$, i.e., each borrower, if monitored, would rather invest in Project 1 and repay the loan, than cheat by investing in Project 2 and suffer social sanctions.

Let us now consider three cases. 
- Suppose first that neither borrower is monitored. In this case, both borrowers choose Project 2, announce that their projects failed, and receive payoffs of $b$.

- Now suppose that borrower 1 monitors borrower 2, but borrower 2 does not monitor borrower 1 . Then borrower 1 , knowing that he is not being monitored, will choose Project 2, receiving a payoff of $b-m$, while borrower 2, knowing that she is being monitored, chooses Project 1 . This gives her a payoff of $H-r-c$, since she must repay her own loan and in addition pay the lender $c$ as liability for borrower 1's loan. [Since the game is symmetric, the payoffs would be reversed in borrower 2 were to monitor borrower 1.]

- Finally, suppose that both players monitor. Then they both invest in Project 1 , and receive payoffs of $H-r-m$.

We thus arrive at the payoff matrix shown in Figure 1.

\begin{tabular}{|c|c|c|}
\hline & Monitor & Does Not Monitor \\
\hline Monitor & $H-r-m, H-r-m$ & $b-m, H-r-c$ \\
\hline Does Not Monitor & $H-r-c, b-m$ & $b, b$ \\
\hline
\end{tabular}

Figure 1. Monitoring Game in Group Lending

There is clearly a pure strategy Nash equilibrium in which both borrowers do not monitor, since a unilateral deviation from this outcome reduces the deviator's payoff by the cost of monitoring, $m$. However, there would also be a Nash equilibrium in which both players monitor, if $m \leq c$, i.e., if monitoring is not too costly. In this equilibrium, both players choose Project 1 , and the lender is repaid. ${ }^{8}$

If we were to introduce repeat lending as we did in Section 2.1, we would simply add $V$, the present value of future loans, to all the payoffs in the above matrix except the lower right-hand cell, since in all the remaining outcomes the group loan is repaid (assuming $H>r+c$ as we assumed in Section 2.1). In this case, if $V>m$, the equilibrium in which the two borrowers do not monitor would disappear.

We conclude that even in a non-cooperative game, in which the members of the group cannot sign a binding contract, there is an equilibrium in which the members monitor each other (provided that monitoring is not too costly),

\footnotetext{
${ }^{8}$ This conclusion is contrary to that obtained by Chowdhury (2003), who obtains a unique Nash equilibrium in which both borrowers do not monitor. His result, however, is driven by the particular cost-of-monitoring function he chose. In his model, monitoring is a continuous decision variable, denoted $m$, and the cost of monitoring is $m^{2} / 2$. Simply by replacing this cost of monitoring function with $\alpha m+\left(m^{2} / 2 \beta\right)$, where $\alpha$ and $\beta$ are positive constants, and assuming that $m \in[0, \bar{m}]$ where $\bar{m}$ is some upper bound on $m$, he would obtain two Nash equilibria (one dynamically stable and one unstable) in which both agents monitor, assuming that $\beta(H-r)>1$.
} 
leading to the lender being repaid. In contrast, given our assumption that the lender cannot monitor individual borrowers, this result would not be obtained under individual lending.

\subsection{The Enforcement Problem}

Until now, we have assumed that the only problems limiting the ability of lenders to lend to small, poor borrowers derive from asymmetric information. There is an additional problem, however, that would be present even if information was perfect: the enforcement problem. When using the legal system is very costly, and borrowers have no collateral, or legal difficulties make repossessing collateral difficult, it will be hard for lenders to enforce the terms of the loan contract. To be sure, the threat that future loans will not be granted to defaulters will deter default in many cases, but this threat will not always be effective. A borrower, for example, may not be interested in future loans, or competition from alternative lenders may make the threat ineffectual. ${ }^{9}$

The enforcement problem in group lending has been analyzed by Besley and Coate (1995), who introduce a "social penalty function" which allows groups to enforce their members' loan obligations. If a borrower's project succeeds and nevertheless he or she "strategically" defaults, the borrower bears a cost imposed by his or her fellow group members. The members of the group have an incentive to apply such sanctions even if they are costly to impose, because they will not be able to receive loans from the same lender in the future if the group defaults, or alternatively they will have to make up for the lost repayment revenue deriving from strategic default in order for the group not to default.

Besley and Coate (1995) showed that if the social sanctions imposed are severe enough, repayment rates under group lending will exceed those under individual lending. This is certainly not a surprising result. Interesting questions arise, however, when we consider the effects of various changes in the technological and social environment on the incentives of group members to apply such sanctions.

A pioneering attempt to address these issues was made by Armendáriz de Aghion (1999). Following Besley and Coate (1995), Armendáriz de Aghion (1999) assumes random project returns which are exogenous to the borrowers' behavior (i.e., effort does not affect return). Actual returns (which may be either "high" or "low") are private information, but can be observed by the members' peers through monitoring. A member who receives a "high" return on her investment project and nevertheless defaults, is termed a strategic defaulter. The model supposes that strategic default, when detected, will be sanctioned severely enough to deter such default. Armendáriz de Aghion (1999) studies the effects on members' monitoring decisions of (a) the correla-

\footnotetext{
${ }^{9}$ Lenders, of course, can share information of defaults, thus mitigating this negative effect of competition. There is empirical evidence, however, that competition between alternative lending institutions indeed weakens the threat of not obtaining loans in the future. This evidence will be reviewed in Section 3 .
} 
tion of members' returns, (b) group size, and (c) the monitoring "structure" (i.e., the structure determining who monitors whom and when). The results of Armendáriz de Aghion (1999) regarding the correlation of members' returns seem not be very robust to the specification of the model. ${ }^{10}$ Her results regarding monitoring structure are illustrative at best (she does not try to examine all possible monitoring structures, and indeed this may not be possible to do). I therefore focus on her results regarding group size.

Armendáriz de Aghion (1999) finds that the net effect of increased group size on repayment rates is ambiguous, and identifies four distinct effects of group size, three of which lead to a positive effect of group size on repayment rates:

- The first effect is the "free-riding" effect, and is the only reason to expect increased group size to negatively affect repayment rates. Quite simply, as the group becomes larger, it becomes more likely that at least one member will obtain the high output realization and be able to repay the entire group loan. [Armendáriz de Aghion (1999) assumes that a high output realization is large enough to repay the entire group loan-a highly unrealistic assumption for large group sizes.] Members therefore have less incentive to monitor each other, leading to more strategic default.

- The "joint-responsibility" effect. If group member A monitors a group member B, this not only eliminates the possibility that B will strategically default, which would have forced A (if he achieves the high output realization) to repay B's debt. It also eliminates the possibility that $\mathrm{B}$ will avoid repaying his share of the debt of group member C, who obtained the low output realization and therefore cannot repay her debt, which again would have forced A to repay her debt. With increased group size, more members will obtain the low output realization, increasing member A's incentive to monitor potential strategic defaulters like member B.

- The "cost sharing" effect. As the group becomes larger, each member can monitor each other member with a lower probability and still the group as a whole will achieve the same probability that each member will find himself monitored. Thus the cost of monitoring, per (monitored) peer, decreases, and this increases the incentive to monitor.

- The "commitment" effect. Each member's incentive to monitor increases with increased group size, simply because the potential number of strategic defaulters increases with increased group size, thus increasing the potential cost to each non-delinquent member of repaying the debts of the defaulters.

\footnotetext{
${ }^{10}$ Ahlin and Townsend (2003), in generalizing the model of Besley and Coate (1995), obtain a result precisely opposite to that of Armendáriz de Aghion (1999).
} 
The theoretical ambiguity of the net effect of group size suggests that empirical studies could profitably look for non-linear effects of group size on repayment rates. This issue has obvious practical importance in the design of group sharing programs.

\section{Empirical Evidence}

This section surveys the empirical evidence available on the effects of group liability and the determinants of the success of group lending schemes. The empirical studies have moved from an examination of the effects of alternative liability rules (Bratton, 1986), to general empirical studies of the determinants of repayment performance (Sharma and Zeller, 1997; Zeller, 1998; Godquin, 2002; Ahlin and Townsend, 2003), and finally to a focus on the effects of monitoring and social connections within groups of borrowers (Wenner, 1995; Wydick, 1999; Paxton et al., 2000; van Bastelaer and Leathers, 2002; Kritikos and Vigenina, 2005; Karlan, 2005). I survey these groups of studies in turn.

\subsection{Effects of Alternative Liability Rules}

In the first systematic study of group lending schemes, Bratton (1986) reports on a study of group versus individual lending programs in Zimbabwe. In the period under study, small farmers in Zimbabwe received loans from two sources: the government-sponsored Agricultural Finance Corporation (AFC), and non-governmental organizations (NGOs), notably Silveira House (SH), a Catholic training center. Lending by commercial banks and informal moneylenders was virtually absent. The loan programs of AFC and SH were similar in that loans were made in kind rather than in cash. In-kind loans included "crop packs" of seed, fertilizer, and chemicals. AFC also financed tractor ploughing and, occasionally, hired labor for cotton and tobacco growers.

A second similarity between the two sources of credit was that neither could repossess collateral of the borrowers. Instead, to the extent this was feasible in practice, loans were guaranteed by a lien on crop output. Crops were marketed via a marketing board, and a "stop order" was placed for the value of loans received by the farmer. Bratton, however, implies that the method of liens on crop output was only a partial solution to the default problem. Bratton (1986, p. 127) indicates that there were "unofficial marketing channels" in addition to the marketing boards, so that farmers could avoid repaying in practice.

The AFC operated two lending schemes: an individual lending scheme and a group lending scheme. While loans were administered through the medium of groups of farmers in both cases, under the individual lending scheme borrowers were only liable for repayment of their own loans. Under the group lending scheme, in contrast, the group as whole was liable for the debts of its members. Bratton terms the group liability system used by the AFC "mandatory" group liability, in contrast to the "voluntary" group liability scheme employed by SH. Under the mandatory joint liability arrangement, a stop order was used in order to ensure that the group repaid its debts. Loans 
were made to the group as a whole, and individual farmers were expected to market their produce through the group, to official marketing boards. Under the voluntary group liability scheme employed by SH, each farmer was liable for repayment of his or her loans. However, if any member of the group defaulted, the entire group became ineligible for future loans.

One dimension of performance of microfinance schemes is that of administrative costs and losses to the lending organizations through default. Table 1 shows administrative costs and losses due to default for the three lending schemes outlined above.

Table 1. Costs and Returns for Microfinance Programs in Zimbabwe

\begin{tabular}{|l|l|l|l|}
\hline Lending institution & AFC & SH & AFC \\
\hline Liability type & individual & voluntary group & mandatory group \\
\hline \hline Costs* & & & \\
\hline Administrative (1983) & 11 & 12 & 1 \\
\hline Default (1980-82) & 46 & 28 & 15 \\
\hline Total Cost & 56 & 40 & 16 \\
\hline Rate of Return** & -50 & -37 & -5 \\
\hline
\end{tabular}

Source: Bratton (1986), Table 7.

*As percentage of loan capital. **Annual (pct.) rate of return, net of inflation.

As Table 1 makes clear, the most cost-effective method of providing microcredit in Zimbabwe was mandatory group credit. Administrative costs were lower using mandatory group credit, since the lending institution did not have to keep records for individual borrowers. (Under voluntary group credit, borrowers were not formally liable for each other's debts, as noted above, but only faced a collective penalty of inability to receive future loans if any group member defaulted.) In addition, default was considerably lower under mandatory group credit.

Bratton reports, however, an interesting reversal of the repayment superiority of group credit in bad growing seasons. Table 2 shows loan recovery rates for three time periods. 1980-81 was a very good growing season, with bountiful rains and a bumper crop. 1981-82 was drier than normal, and crops were damaged, but not destroyed. 1982-83 saw a disastrous nationwide drought. In the first two time periods, recovery rates under group credit were distinctly higher than under individual credit, with mandatory joint liability performing best. In the 1982-83 season, the recovery rates under all three systems fell sharply, due to simple inability to repay owing to the drought. But, interestingly, the recovery rate under individual credit was higher than under group credit during this season. 
Table 2. Loan Recovery Rates for Microfinance Programs in Zimbabwe

\begin{tabular}{|l|l|l|l|}
\hline Lending institution & AFC & SH & AFC \\
\hline Liability type & individual & voluntary group & mandatory group \\
\hline \hline $1980-81$ & 53 & 72 & 92 \\
\hline $1981-82$ & 54 & 71 & 78 \\
\hline $1982-83$ & 28 & 18 & 9 \\
\hline \multicolumn{2}{|r|}{ Source: Bratton (1986), Table 6. Figures are percentages. } \\
\hline
\end{tabular}

The poor relative performance of group liability during the drought of 1982-83 is easily explained by Bratton (1986, p. 126):

Group lending...appears viable under 'normal' conditions, but counterproductive when farmers are exposed to extreme environmental stress. The logic of collective action in different organizational settings supports this view. Individuals will struggle to repay even when they are stringently deprived in order to maintain eligibility for credit. By contrast, farmers with joint liability loans have little incentive to pay their share unless they expect other group members to do the same.

In other words, given a sharp negative environmental shock, under group lending, the few successful farmers will have to repay not only their own debts, but also those of their relatively many, less fortunate peers. Faced with the low probability that the other successful farmers will be willing or able to repay, each individual successful farmer has an incentive to avoid repaying altogether, since repaying will be furthering a "lost cause." Under individual liability, each successful farmer knows that he will be held liable only for his own debts, so his incentive to repay is unaffected by the failure of his peers to repay. In normal growing seasons, however, this positive effect of individual liability is outweighed by the positive effects of group liability, outlined in Section 2.

The reversal of the relative performance of voluntary and mandatory group liability, when comparing 1980-81/1981-82 and 1982-83 growing seasons, remains a puzzle, however. Bratton tries to explain this reversal as well, but his explanation here is less convincing.

\subsection{Determinants of Repayment Rates}

This subsection surveys four empirical studies that focus on the determinants of repayment performance in group lending schemes. The first three of these studies, (a) Sharma and Zeller (1997) on Bangladesh, denoted below as SZ, (b) Zeller (1998) on Madagascar, denoted Z, and (c) Godquin (2002) on Bangladesh, denoted G, make informal arguments for the effects of many of the variables they employ, that are informed by the theoretical work surveyed in Section 2. These arguments will be surveyed below. The fourth study, 
Ahlin and Townsend (2003) on Thailand, denoted AT, develops formal extensions of models presented by earlier authors, and tests these models against each other. This subsection surveys results for variables that were used in two or more studies, comparing the results regarding these variables. In the next subsection, we turn to the studies individually and survey the results regarding variables that were used uniquely by each study.

Variables that were used by more than one study include: (a) loan size, (b) group size, (c) average land ownership, (d) share of irrigated land, (e) a dummy variable indicating that the group membership was determined by group members themselves, (f) measures of group cohesiveness, (g) the proportion of group members having relatives in the group, (h) average educational level of the group, and (i) availability of outside credit opportunities. Table 3 summarizes the results regarding these variables.

Table 3. Summary of Regression Results for Determinants of Repayment Performance

\begin{tabular}{|l|l|l|l|l|}
\hline & SZ & Z & G & AT \\
\hline Loan Size & negative & - & positive & positive* \\
\hline Group Size & insig. & positive & mixed & insig. \\
\hline Land Ownership & positive & insig. & positive & insig. \\
\hline Share of Irrigated Land & negative & positive & - & - \\
\hline Self-Selection & positive & insig. & - & - \\
\hline Group Cohesiveness & positive & positive & mixed & mixed \\
\hline Relatives & negative & - & - & insig. \\
\hline Education & - & insig. & negative & positive \\
\hline Outside Credit Opportunities & negative & - & negative & negative \\
\hline
\end{tabular}

*Nonlinear effect: squared term negative and significant.

The table lists as positive or negative effects only those statistically significant at least at the 0.1 level. In the remaining cases where the relevant variable was included in the regression, the coefficient is indicated as insignificant. The Ahlin-Townsend (AT) study reported results separately for two regions of Thailand, together with the results for the combined sample. The coefficients reported in the AT column are listed as significant if they were statistically significant in one or more of the three AT logit regressions.

The dependent variables in the four studies differ, but all basically measure the same concept. In SZ, the dependent variable is the delinquency rate (rather than repayment rate) on individual loans, defined as the share of the loan amount in arrears at the promised date of complete repayment. To make the results of SZ comparable to those of G, Z and AT, the results in Table 3 for this study show the reversed sign of the relevant variable's coefficient. In $\mathrm{Z}$ and $\mathrm{AT}$, the observations were on the group, rather than the individual level. In $G$ and $Z$, the dependent variable is the "repayment rate." $G$ tried 
two definitions of the repayment rate: (a) full repayment on time, and (b) repayment on time or within a three-month grace period. In Z, this variable's precise definition is left somewhat vague: it could be the share of loans fully repaid, fully or partially repaid, or the average share of the loan amounts repaid. In AT, the dependent variable is a proxy of the repayment rate, namely a dummy variable taking the value of 1 of the lending agency never raised the interest rate on its loans to the group as a penalty for defaulting, and 0 if the lending agency had raised the interest rate at least once as a penalty.

Let us examine the results obtained for each of the variables listed above.

Loan Size. Loan size, being an instrument usually at the discretion of the lending institution, is a variable of particular interest when studying the determinants of repayment performance. SZ and AT consider conflicting hypotheses regarding the expected sign of the coefficient of this variable. SZ argue that delinquency is likely to be zero for very small loans. The penalty of not receiving future loans will apply even when only a small sum is in arrears, while in the case of a small loan, the cost of repaying is correspondingly low. Thus, in the case of small loans, borrowers will try harder to repay. In addition, for a given group size, larger loans imply larger risks to each (repaying) borrower in the event that he or she will have to repay the loans of other borrowers in the same group. This may increase each borrower's incentive to default. AT also predict a negative effect of loan size on repayment, in their extensions of the moral hazard models of Stiglitz (1990) and Banerjee, Besley, and Guinnane (1994). But in their extension of the Ghatak (1999) adverse selection model, they predict a U-shaped effect of loan size on repayment. This theoretical result, however, appears to be driven by the particular assumptions AT made in their extension of the Ghatak (1999) model.

$\mathrm{G}$ and AT obtain a positive, significant effect of loan size on repayment performance. More specifically, the empirical result obtained by AT was a positive, but nonlinear (concave) effect in the central region of Thailand. In the poorer, northeast region, AT did not obtain an significant effect of loan size. Their observed positive effect of loan size in the central region may simply be an artifact of self-selection bias, since AT report that loan sizes in the program they studied increase gradually as the borrower increases his seniority within the program and proves himself to be a borrower who repays his debts. Thus larger loans would be correlated with relatively low-risk borrowers. This explanation, however, cannot be used to explain the positive effect obtained by $\mathrm{G}$, since in her main regressions, loan size is proxied by an instrumental variable that (with the possible exception of one subsample) presumably is not significantly correlated with the borrower's seniority in the loan program.

SZ, in contrast, obtain a negative effect of loan size on repayment. Their result may be a consequence of the particular specification they used in their regression, in which loan size was interacted with each of the explanatory variables in addition to being a separate explanatory variable. 
Group Size. In Section 2.3, we noted that the effect of group size on repayment is theoretically ambiguous. Empirically, SZ and AT do not find a significant effect of group size, while Zeller (1998) obtains a positive and significant effect. It should be noted, however, that group lending programs have tended to keep group size small - on the order of 5 to 10 members. This suggests that a quadratic, rather than linear, relationship of group size to repayment performance, should be estimated. The results of Godquin (2002) lend support to the hypothesis of a nonlinear effect of group size on repayment. Instead of entering group size as a continuous variable, she uses dummy variables for various group sizes. The "reference" group size for the comparisons in her regressions is the intermediate size, between 16 and 30 members. The smallest group size (at most 10 members) is positively and significantly related to repayment performance in her regressions using her combined sample, which includes three different microfinance programs, when "repayment" is defined as repayment of the entire loan on time. However, in a regression that uses OLS (as opposed to her preferred IV specification) when "repayment" is defined to include the three-month grace period, the smallest group size has a negative and significant effect. In addition, the largest group sizes, from 31 to 50 and from 51 to 81 members, receive positive and significant coefficients in some of her regressions for the entire sample. This U-shaped effect of group size, however, is precisely reversed in her regression for one of the subsamples (the BRAC program), and fails to appear in the remaining regressions for her subsamples.

Land Ownership. Land ownership has been hypothesized to positively affect repayment, for two reasons. First, land ownership is a measure of wealth. The wealthier the borrower, the more likely she is able to find ways of repaying her debt when her farm or business is hit by a negative shock, like a drought. Similarly, she will be more likely to repay fellow group members' debts when they are hit by such shocks. A second reason for the hypothesized positive effect of land ownership is that land can serve as collateral (which can be seized either the lender, or, where this is infeasible, by other group members), inducing the borrower to repay her debt, and reducing the group's dependence on joint liability as an inducement to repay. Thus AT use the proportion of group members who do not own land as a measure of the degree of joint liability ( $c$ in the equations of Sections 2.1 and 2.2 above). In addition to this variable, AT include the average amount of land owned as a separate explanatory variable. SZ obtain a significant, positive effect of average land ownership on repayment, while $\mathrm{Z}$ and AT do not obtain a significant effect for this variable. AT's measure of $c$, however, receives a negative and significant coefficient in the Central region and in their overall sample. AT argue that this negative effect is predicted by the models of Stiglitz (1990) and Ghatak (1999). It could be argued, however, that since $c$ is negatively correlated with average wealth, a negative coefficient would be predicted in any case, despite the fact that average land ownership is included as a separate explanatory variable. This could happen if there are important measurement errors in 
the average land ownership variable, or if multicollinearity problems affect the joint estimation of the two variables' coefficients, or if there is a discrete effect when one goes from zero to "some" land ownership.

$\mathrm{G}$ does not include land ownership as an explanatory variable, but does include the value of the household's productive assets, presumably highly correlated with the value of its land. This variable receives a positive and significant coefficient in her combined-sample regressions when the repayment variable is defined to be repayment of the entire loan on time. (When the three-month grace period is allowed in the definition of "repayment," the coefficient becomes insignificant.) Positive and significant coefficients are obtained for this variable in each of the subsample regressions, as well.

Share of Irrigated Land. Since irrigated land is more productive and less subject to risks caused by climatic factors, the share of irrigated land proxies for average wealth (as does the percentage of group members owning land, considered above) and lower risk. We would therefore expect a positive coefficient to be received by this variable. $\mathrm{Z}$ indeed obtains a positive and significant coefficient, but SZ obtain a negative and significant coefficient. SZ argue that poorer borrowers will be relatively more dependent on formal credit programs like group lending schemes, making the penalty of not receiving future loans a more powerful incentive. This argument, of course, implies that the effect of wealth on repayment performance is theoretically ambiguous.

Self-Selection. According to the notion that group lending schemes work largely because members can screen other members when they form a group, advanced by Wenner (1995), Ghatak (1999), van Tassell (1999), and Laffont and N'Guessan (2000), we would expect groups that form themselves (rather than being assembled by an agent of the lending institution) will exhibit relatively high repayment rates. SZ indeed obtain a positive, statistically significant coefficient for this variable, while $\mathrm{Z}$ obtains an insignificant coefficient, and $\mathrm{G}$ and $\mathrm{AT}$ do not include this variable in their regressions.

Group Cohesiveness. All four studies include various measures of the degree to which the group cooperates successfully in other spheres of activity. SZ include the number of participants (per 1,000 inhabitants of the village) who participate in group-based institutions. This variable receives a positive and significant coefficient. Z includes a variable called "number of common bonds," such as group members coming from the same village, from the same hamlet, belonging to the same ethnic group and religion, and belonging to the same extended family. This variable receives a positive and significant coefficient. $G$ includes three measures of group homogeneity, which are dummy variables indicating whether the respondent and the group leader were of the same gender, had the same educational level (within two years), and were of the same age (within five years). These are clearly crude measures of group homogeneity; they measure only the similarity of the individual respondent and the group leader. The results using these variables are puzzling. "Same gender" receives consistently positive coefficients where the coefficient is statistically significant. "Same educational level," in contrast, receives consis- 
tently negative coefficients, when significant. "Same age" receives one positive and one negative significant coefficient for G's subsample regressions, and insignificant coefficients for her entire sample. AT include a number of variables to measure the degree of cooperation in the group. A measure of the degree of cooperation among non-relatives (e.g., coordinating to purchase inputs, helping with money, helping with free labor, etc.) receives a negative and significant coefficient for their combined sample. A second variable, measuring the number of productive decisions (e.g., regarding pesticides, fertilizer, and which crops to grow) which are made jointly by the group, receives a positive and significant coefficient for the central region and for their combined sample. A third variable, based on a survey question asking residents of the subcounty (tambon) who named the village as best in the tambon for "cooperation among villagers," receives a negative and significant coefficient in the northeast region. AT note that the existence of strong social ties among group members may make it more costly for them to apply sanctions to defaulting members. On the other hand, social capital, as a measure of the success of the village in solving the free-rider problem, is generally assumed to enhance the ability of the group to punish defaulters. This may explain the mixed results that they obtain.

Relatives. The proportion of group members who are relatives is expected to have an effect on repayment performance similar to the measures of group cohesiveness considered above. SZ obtain a positive and significant effect for this variable, while AT do not obtain a significant coefficient.

Education. Z and AT hypothesize that increased human capital should improve the repayment rate. Just as physical wealth (measured by land ownership) increases the members' ability to sustain adverse shocks and still repay their loans, we would expect a similar effect for human capital. AT indeed obtain a positive and significant coefficient for their measure of average educational attainment in the northeast region and in their combined sample. $\mathrm{Z}$ does not obtain a significant coefficient for this variable. $\mathrm{G}$ includes this variable as well, without discussion of its predicted coefficient. She in fact obtains negative and significant coefficients in three of the four reported regressions for her entire sample (in the remaining regression, the coefficient is also negative, but insignificant). A possible explanation might be that with increased human capital, the borrower has increased opportunities to borrow from alternative lending sources, reducing the threat of not receiving loans in the future if he or she defaults.

Outside Credit Opportunities. The availability of credit outside the group lending program will diminish the threat of not obtaining further group loans when the group defaults. For this reason, a negative coefficient is expected for this variable. On the other hand, availability of credit from alternative sources may improve the borrower's ability to repay his loans when hit by negative shocks, arguing for a positive coefficient. The three studies (SZ, G, and AT) that test for such an effect both obtain a negative and significant coefficient. 
SZ include two variables that directly proxy ${ }^{11}$ for outside credit opportunities: (a) mean distance to nine types of service centers (e.g., post office, health post, and agricultural input dealers), a variable which will be larger, the more costly it is to access alternative credit sources, such as loans from traders and employers, and (b) a variable measuring the number of mutual self-help and insurance groups in the village. ${ }^{12} \mathrm{G}$ includes a variable that measures social ties outside of the village: a dummy variable taking the value of unity when the borrower's spouse lives elsewhere. This variable receives negative and significant coefficients when the repayment variable is defined as complete repayment on time. Social ties outside the village presumably are positively correlated with outside credit opportunities. AT obtain a significant, negative coefficient (in their sample for the northeast region and in their combined sample) for the percentage of group members who are also members of a village credit cooperative called a "production cooperative group."

\subsection{Results from Individual Studies}

We now return to the three studies surveyed in the previous subsection, discussing the main variables that gave statistically significant results yet were not surveyed above. We then turn, in the following subsection, to other studies that focus on the role of group lending as a screening device as well as a means for increasing sanctions on delinquent borrowers.

\subsubsection{Sharma and Zeller (1997)}

SZ include a measure of credit rationing in their regression: the difference between the value of the loan applied for and the loan actually received, as well as the square of this variable. This variable receives a positive ${ }^{13}$ and significant coefficient in its linear form. SZ interpret this result as indicating that when there is excess demand for credit, borrowers will be relatively more highly concerned with obtaining future loans, thus increasing $V$ in terms of the analysis of Sections 2.1 and 2.2, and increasing the borrower's incentive to repay. The coefficient of the squared term of the same variable receives the opposite sign, and is also statistically significant. SZ argue that when the value of the loan is very small relative to the value of the loan applied for, the credit source will tend to be viewed as "trivial" from the borrower's viewpoint, reducing the borrower's incentive to repay.

SZ use, as an additional regressor, the proportion of members who report agriculture as their main occupation. SZ report that in 68 percent of their observations, this proportion was equal to zero, and the mean of this variable

\footnotetext{
${ }^{11} \mathrm{SZ}$ also include a variable, the proportion of borrowers in the group reporting agriculture as their primary occupation, which they argue also may proxy for availability of credit from alternative sources. See Section 3.3.1 below.

${ }^{12}$ Note that the latter variable may also measure the stock of social capital in the village, yet its estimated effect on the repayment rate is still negative and significant at the 0.1 level.

${ }^{13}$ Recall that the dependent variable in SZ is the rate of loan delinquency, rather than repayment. I therefore reverse the signs of all coefficients as they are reported in SZ, to make the results comparable to those of the other studies surveyed.
} 
was 8 percent. In other words, most of the borrowers in their sample worked as hired laborers in non-agricultural occupations, a consequence of the lending institutions' requirement that borrowers not possess land in excess of one-half acre. Those who report agriculture as their main occupation are therefore likely to be tenant farmers. SZ argue that such farmers will tend to have more alternative sources of credit (from their landlords) than those who work primarily outside of agriculture as hired laborers. SZ obtained a positive and significant coefficient for this variable, which appears to contradict their results (reported above in Section 3.2) regarding the effect of availability of alternative credit sources.

SZ also report a result suggesting that wealth may actually have a negative effect on the repayment rate, in line with the result they obtain for the percentage of land irrigated (reported above in Section 3.2), but in contrast to the overall thrust of the results reported in Section 3.2 indicating that wealth (as measured by land ownership) has a positive effect on repayment performance. Specifically, SZ include a dummy variable indicating that the village had a "food-for-work" (FFW) program in place, indicating that the village is relatively poor. The FFW dummy receives a positive and significant (at the 0.1 level) coefficient, suggesting that higher wealth may reduce repayment performance. As noted in Section 3.2, SZ argue that when borrowers are wealthier, they become less dependent on formal sources of credit such as the group lending program, thus reducing the threat of not receiving future loans if the borrower defaults.

Finally, SZ include two regressors that may proxy for risk-aversion: the average dependency ratio in the group, and the percentage of female group members. SZ argue that when the dependency ratio (proportion of children in the household) is high, borrowers will tend to be more risk-averse. Similarly, they argue that female borrowers (given the dominant role of males in Bangladeshi society) will be concerned about receiving reprimands from their husbands if their projects fail and they are delinquent in repaying debts, a factor absent when the borrower is a male. One might add that there is experimental evidence from developed countries that females are more risk-averse than males. Both variables receive positive and significant coefficients.

\subsubsection{Zeller (1998)}

Zeller includes a number of community-level characteristics absent from the other studies. One such characteristic is the degree of monetarization of the village (the percentage of marketed production of the three major cash crops of the community). Zeller argues that when this variable is high, borrowers will find it relatively easy to raise cash to repay loans (essentially, this variable measures wealth). The coefficient received by this variable is positive and significant. Similarly, Zeller includes the number of retailers of agricultural inputs per thousand inhabitants. He argues that (purchased) inputs are yieldenhancing, thus increasing borrowers' productivity and their ability to repay. This variable, as well, receives a positive and significant coefficient. 
The mayor of each village was asked which of 14 factors constituted little, modest, or serious risk to farmers in the village. The number of "serious" risks received a negative and significant coefficient. Zeller argues that such risks tend to be positively covariant in the community, indicating the likelihood of negative shocks that impact on all members of the village. In such villages, we would expect repayment rates to be relatively low, since default by one farmer would be relatively unlikely to be "covered" by repayment by another borrower.

Zeller also includes a dummy variable taking the value of unity when the loan program provides members with savings services. Such services can serve as collateral when the borrower defaults, thus improving repayment performance. This variable receives a positive and significant coefficient, as expected.

The variance of land possessed by borrowers is an additional variable included by Zeller in his regression. In particular, Zeller includes the coefficient of variation of (rainfed) upland possessed by members of the group. He hypothesizes that increased variation of landholding will be correlated with higher diversification of income sources by group members ("Malagasy households tend to engage in off-farm activities if upland is scarce," p. 616). Diversification, in turn, will tend to improve repayment performance, because negative shocks affecting one borrower will tend to be covered by other members not suffering such shocks. Too much diversification, however, will increase monitoring costs, Zeller argues. Thus he includes the square of this variable, to test for a nonlinear effect. Consistent with this hypothesis, the linear term for this regressor receives a positive and significant coefficient, while the coefficient of the squared term is negative and significant.

Finally, Zeller includes a dummy variable taking the value of unity when the group has "internal agreements and rules of conduct, either in oral or in written form." Zeller argues that such rules "increase transparency and therefore reduce intragroup frictions and costs of coordination," and therefore hypothesizes that this variable should receive a positive coefficient. The coefficient obtained is indeed positive and statistically significant.

\subsubsection{Godquin (2002)}

Godquin includes a fairly large number of variables in her regressions. I discuss here only the variables that received statistically significant coefficients and have a reasonably clear theoretical rationale for expecting either a positive or negative coefficient.

One variable included by Godquin that receives consistently negative and significant coefficients in her IV regressions is the age of the group. As discussed and documented by Paxton et al. (2000), repayment performance tends to decline over time in group lending schemes. One possible explanation may be that distrust among group members gradually increases over time, when some members try to default strategically under the guise of experiencing negative shocks such as low crop yields. Thus the initial enthusiasm 
that accompanied the setting up of the program gradually wears away-social capital "depreciates," as does physical capital.

Godquin includes dummy variables taking the value of unity when the repayment of the loan had to be completed either (a) at the end of the year or (b) during the harvest period. These dummy variables receive positive and significant coefficients (with one exception in one of the subsample regressions), suggesting that the liquidity of borrowers is higher during these periods.

Measures of the wealth of the borrower display contradictory effects in Godquin's regressions. The positive effect of the value of the household's productive assets was noted above. Similarly, a dummy variable taking the value of unity when the household has "specific garbage disposition" receives a positive and significant coefficient. On the other hand, the level of per capita consumption in the household receives a negative and significant coefficient, when repayment is defined as complete repayment on time.

Godquin includes a number of borrower characteristics not included by the other studies. The age of the borrower is found to have a negative and significant effect on repayment performance (again, with one exception for one of the subsample regressions). This could be explained by the shortening of the borrower's time horizon as he or she ages, reducing his or her incentive to repay loans in order to be able to receive future loans. As in SZ, female borrowers appear to display significantly higher repayment rates than male borrowers.

\subsubsection{Ahlin and Townsend (2003)}

Most of the results obtained by AT were discussed above in Section 3.2. An additional variable included by AT in their regressions is the percentage of village loans in which default is punishable by informal sanctions, including inability to receive loans in the future from the current lender as well as other credit sources, and loss of reputation within the village. This variable receives a positive and significant coefficient in AT's sample from the northeast region.

\subsection{Social Ties and Monitoring Costs}

We now turn to a number of studies that focus on a more narrowly defined set of explanatory variables, generally relating to the effect of social ties on repayment performance in group lending schemes.

Wydick (1999) conducted a survey of 137 borrowing groups in a group lending program in Guatemala. Unlike the studies surveyed above in Sections 3.2 and 3.3, Wydick studied the determinants of three dependent variables: (a) repayment performance (RR), (b) a dummy variable taking the value of unity when there were no instances of misuse of borrowed funds by members of the group (NBBB), and (c) a dummy variable taking the value of unity if group members reported that they help each other with payments if necessary (MUTINS). Wydick's explanatory variables included dummy variables intended to measure (i) the extent of social ties in the group (essentially the 
"group cohesiveness" variable included, in various forms, in the studies surveyed in Sections 3.2 and 3.3), (ii) the willingness and ability of group members to pressure other members to repay their loans, and (iii) the amount of information members have in order to monitor each other's ability to repay. Wydick split his sample into two subsamples, one for urban groups and one for rural groups, as well as reporting results for the combined sample.

In his combined sample, Wydick found evidence that members' monitoring costs indeed have a negative effect on the repayment rate. The average distance between members' businesses received a negative and significant coefficient in Wydick's repayment rate regression, ${ }^{14}$ and a positive and significant coefficient was received by a dummy variable (KNOWSALE) taking the value of unity when members said they knew weekly sales of other members.

In line with Zeller (1998), Wydick found that the number of members in the group was positively and significantly related to repayment performance in the urban subsample. Curiously, in the urban subsample, homogeneity of gender in the group was found to be negatively and significantly related to repayment performance.

When the dependent variable is MUTINS, monitoring costs again turn out to be important. The average distance between members' businesses again receives the expected negative and significant coefficient, while KNOW-SALE again receives positive and significant coefficients (in the urban subsample and in the combined sample). Another dummy variable, taking the value of unity when members were in the same line of business, also received positive and significant coefficients in the rural subsample and in the combined sample. Group size again receives positive and significant coefficients (in the rural subsample and in the combined sample), suggesting the positive effect of group size on diversification of risks. In contrast with Wydick's repayment performance regression for the urban subsample, homogeneity of gender is positively and significantly related with mutual help (in the rural subsample and in the combined sample; insignificant in the urban subsample). And in contrast with the results of Paxton et al. (2000) and Godquin (2002), the age of the group receives positive and significant coefficients in Wydick's mutual help regressions.

Members' willingness to apply pressure on defaulters appears to be important when the dependent variable is NBBB. A dummy variable indicating willingness to apply pressure on others to repay receives a positive and significant coefficient in this regression (in both the rural subsample and in the combined sample). A negative and significant coefficient is received by another dummy variable taking the value of unity when it was reported that applying pressure is difficult. Finally, a positive and significant coefficient is received by a dummy variable taking the value of unity when it was reported that there is a moral obligation to repay group loans. KNOWSALE again receives positive and significant coefficients in the rural subsample and in the

\footnotetext{
${ }^{14}$ The same variable also received a negative and significant coefficient in the regression for the rural subsample.
} 
combined sample.

The overall conclusion that can be drawn from Wydick's results is that low monitoring costs and willingness to apply pressure on fellow group members are important in improving repayment performance and in mitigating moral hazard problems. But Wydick's variables that were intended to measure the strength of social ties in the group (what other scholars call "social capital") generally did not receive statistically significant coefficients.

A paper by van Bastelaer and Leathers (2002), denoted here as VBL, casts doubt on whether social capital organizational structures (as distinct from trust per se) have positive effects on repayment performance. VBL study the determinants of the repayment rate in group seed lending programs in Zambia. Two variables in their regression receive statistically significant coefficients that are consistent with results from studies surveyed above. The first of these variables is a dummy variable taking the value of unity when group size was less than 12 . This variable receives a positive coefficient, suggesting a negative effect of group size on repayment performance, a result which conflicts with results obtained by Zeller (1998) and Wydick (1999), but is consistent with some of the results obtained by Godquin (2002). The second variable measures "generalized trust", indicated by a negative response to the question, "Are villagers likely to take advantage of each other?" This variable receives a positive coefficient, as one would expect: the higher the level of trust in the community, the more likely will the borrowing group solve free-rider problems and repay its debts.

Other variables in VBL's regression, however, suggest that what VBL call "structural" social capital actually has a negative effect on repayment performance. The frequency of group meetings, for example, receives a negative and significant coefficient. VBL suggest that this result may be caused by reverse causality: groups that have difficulty repaying their debts may have more meetings than more healthy groups, in order to solve their repayment problems. Other unexpected results, however, cannot be explained away in this fashion. A dummy variable taking the value of unity when church groups exist in the community also receives a negative and significant coefficient. In addition, a variable indicating participation of group members in the same church receives a negative and significant coefficient. These results suggest that when social ties are too "dense," willingness to apply social pressure on defaulters may decline, more than offsetting the positive effects of social capital on the ability of the group to cooperate.

Kritikos and Vigenina (2005), denoted here as KV, provide interesting evidence on the presence of assortative matching in group lending schemes, an issue which we discussed on the theoretical level in Section 2.1. KV studied a group lending program called Constanta in the former Soviet republic of Georgia. In a survey KV conducted of 108 groups in the Constanta program, a (randomly selected) group member was asked how he or she evaluated the riskiness of the business projects of his or her fellow group members, on a scale ranging from "all businesses were quite risky" to "all businesses were quite 
safe." This variable, which KV denote "group quality," was regressed, in an ordered logit specification, on the respondents' own risk type, as measured by a cluster analysis based on (a) the respondent's average monthly income, (b) the respondent's assessment of the change in his or her monthly income since the first loan disbursement, and (c) the respondent's assessment of the stability of his or her business project. KV found that group quality is positively and significantly related to the respondent's own risk quality, suggesting the presence of assortative matching. As an aside, in the same regression, the quality of information members have of each other's business projects (again as reported by the randomly selected survey respondent) was found to have a significantly positive effect on group quality.

A second innovation of the KV study is to distinguish empirically between internal and external loan delinquency. Internal delinquency occurs when group members default on their loans, but other members compensate by repaying the delinquent member's debt. External delinquency occurs when the group fails to repay a member's debt.

When the dependent variable is a dummy variable taking the value of unity when there was no internal delinquency, only two explanatory variables receive statistically significant coefficients: (a) a dummy variable ("peer support") taking the value of unity when the respondent expressed preference for group liability contracts over individual liability contracts, which receives a positive coefficient (i.e., positive relationship with repayment performance), and (b) a variable ("peer control") measuring the frequency of group discussions of business problems within the group, which surprisingly receives a negative coefficient. KV - like VBL, who obtain a similar result - explain the latter result by asserting the presence of reverse causality: where the group has difficulties in repaying loans, there tend to be more group meetings.

When the dependent variable measures the absence of external delinquency, four explanatory variables receive statistically significant coefficients: ${ }^{15}$ (a) group quality, as defined above, (b) a factor analysis score measuring the degree of peer pressure and sanctions (internal and external) applied on delinquent borrowers, (c) the frequency of visits by the Constanta loan officer to the group ("staff pressure"), and (d) the respondent's assessment of the correlation of members' project returns. The coefficients of variables (a) through (c) are positive, and that of variable (d) is negative. The latter result supports the hypothesis suggested in previous studies [e.g., Zeller (1998)] that lower correlation of returns across members' projects improves members' ability to repay each others' debts when some projects fail.

Karlan (2005) studies a group lending program, FINCA, in Peru, with the aim of providing further evidence that social ties are important in promoting the success of such programs. Karlan argues that the fact that borrowing

\footnotetext{
${ }^{15} \mathrm{I}$ report here the results of KV's regression in which the dependent variable indicates that only internal delinquency was observed, but no external delinquency. This regression captures the marginal effects of the variables in explaining external repayment performance, without mixing in the determinants of internal repayment performance.
} 
groups generally form themselves (are self-selected) creates econometric problems for studies of this type. For example, as Karlan observes, "[I]f groups are formed around neighborhoods, and neighborhoods with stronger social networks also have more economic opportunities, then empirically one should observe a correlation between the social connections of a group and its likelihood to repay," even though "social connections" are not the cause of higher repayment performance. Karlan's study avoids this problem in part because the FINCA groups were usually not self-selected, but rather were set up by the lending institution. Secondly, Karlan restricts his empirical analysis to observations in which the individual was not invited to join the group by another member who previously joined the group. These features of the analysis allow Karlan to claim that variables relating to the strength of group connections, such as average distance between members, are indeed exogenous to repayment performance.

In the FINCA program, members receive loans from two sources: (a) external loans, from FINCA, and (b) internal loans, from a savings pool set up by FINCA and funded by the members themselves. In Karlan's sample, the external repayment performance of the borrowing groups was 100 percent. Default, when it occurred, was always covered by the individual's own savings or the savings of other members of the group. His analysis of repayment performance therefore focuses on repayment of internal loans taken from the group savings pool.

The Peruvian village of Ayacucho, where Karlan's data were collected, is culturally heterogenous, consisting of a mixture of indigenous people and individuals of Spanish descent. Karlan constructed a "culture score" measuring the degree to which each individual was "indigenous" or Western, and then calculated the probability that each individual has the same culture score as a randomly chosen individual from the group. Western individuals, incidentally, were found to repay their debts significantly more frequently than indigenous individuals.

When the dependent variable is the default rate (default as a percentage of the potential loan), ${ }^{16}$ Karlan finds that this rate is negatively and significantly related to a measure of geographic proximity between the borrower and other group members, as well as negatively and significantly predicted by the percentage of members whose culture score is the same as that of the borrower. These results confirm the findings of earlier studies that social connections indeed improve repayment performance.

\section{Concluding Remarks}

We have seen that there are good reasons to expect repayment performance to be higher in group lending schemes than under individual liability, in the context of loans to the very poor in developing countries. Group lending harnesses the information that villagers have of each other's investment projects

\footnotetext{
${ }^{16}$ The individual's "potential loan" is defined as her last loan amount plus accumulated savings.
} 
and use or misuse of borrowed funds - information to which external lending agencies have little or no access. Thus credit market failures resulting from asymmetric information, in particular adverse selection and moral hazard problems, can be attenuated. In addition, group members can apply sanctions to defaulters which are unavailable to lending institutions, reducing enforcement costs.

In the empirical literature on microfinance, there is considerable evidence that social ties of group members, which are enhanced by geographical proximity and cultural homogeneity, improve repayment performance by making monitoring of defaulting less costly. When social ties are too strong, however, repayment rates may be impaired because of members' reluctance to apply sanctions to defaulters. In addition, there is consistent evidence that when two or more microcredit programs compete in the same locality, repayment rates decline due to the reduced threat of withholding of future loans from defaulting groups. Aside from these results, however, the results of available empirical studies are contradictory with respect to virtually all potential determinants of repayment performance.

There is thus a need for more empirical work, as well as theoretical studies to clarify the effects of a number of characteristics of group lending programs, so as to improve the design of such programs in the future. For example, the effect of group size on repayment performance is both theoretically ambiguous and unclear from the empirical studies that have examined the effect of this variable. In addition, well designed empirical studies are needed to assess the extent to which group liability actually improves the performance of microfinance programs. Given the vast scale of microfinance programs around the world and the demonstrated potential of such programs in alleviating poverty and promoting economic development, the payoff of further research is clear. 


\section{Appendix}

Suppose there are two types of borrowers, risky (type $a$ ) and safe (type $b$ ). Each borrower takes a loan to finance a project which has probability of success $p_{i}(i=a, b)$ where $p_{a}<p_{b}$. If the project succeeds, it yields income $H$, while if it fails, it yields zero income. As specified in Section 2.1, the borrower takes a loan of one unit of capital, and undertakes to pay $r>1$ (principal plus interest) at the end of the loan time period. Two borrowers form a group taking a group loan, in which each borrower undertakes to pay $c$ if his or her co-member defaults. The terms of the contract, $r$ and $c$, are exogenous variables in this analysis - we are not inquiring into the optimal contract, unlike Laffont and N'Guessan (2000) for example, but rather analyzing a generic case similar to the group lending contracts used in practice. In the event of failure of his or her own project, the borrower pays nothing (i.e., the borrower has no collateral). Assuming that both borrowers are risk-neutral, ${ }^{17}$ borrower $i$ 's expected payoff of taking a loan together with borrower $j$ is

$$
\begin{aligned}
E \pi_{i j} & =p_{i} p_{j}(H-r)+p_{i}\left(1-p_{j}\right)(H-r-c) \\
& =p_{i}(H-r)-p_{i}\left(1-p_{j}\right) c .
\end{aligned}
$$

The first term in the second line is borrower $i$ 's expected net payoff from his own project, and the second term is his expected cost from failure of the project of borrower $j$. [Note that borrower $i$ must bear (part of) the cost of borrower $j$ 's failure, $c$, only if his own project succeeds. Thus the probability that he will have to pay the cost $c$ is the probability that his own project succeeds $p_{i}$ and borrower $j$ 's project fails, $\left(1-p_{j}\right)$, i.e., $p_{i}\left(1-p_{j}\right)$.]

Thus the expected payoff to a safe borrower of taking a loan together with another safe borrower is

$$
\begin{aligned}
E \pi_{b b} & =p_{b} p_{b}(H-r)+p_{b}\left(1-p_{b}\right)(H-r-c) \\
& =p_{b}^{2} c+p_{b}(H-r-c) .
\end{aligned}
$$

In contrast, the safe borrower's expected payoff of taking a loan with a risky borrower is

$$
\begin{aligned}
E \pi_{b a} & =p_{b} p_{a}(H-r)+p_{b}\left(1-p_{a}\right)(H-r-c) \\
& =p_{b} p_{a} c+p_{b}(H-r-c) .
\end{aligned}
$$

Subtracting (2) from (1), we have

$$
E \pi_{b b}-E \pi_{b a}=p_{b}\left(p_{b}-p_{a}\right) c>0 .
$$

This expression measures the safe borrower's relative preference to form a group with another safe borrower. Similarly, the risky borrower's relative preference to form a group with a safe borrower is

$$
E \pi_{a b}-E \pi_{a a}=p_{a}\left(p_{b}-p_{a}\right) c>0
$$

\footnotetext{
${ }^{17}$ I employ the standard simplifying assumption of risk-neutrality.
} 
Note that while both (3) and (4) are positive, (3) is larger than (4), since $p_{b}>p_{a}$. Thus, while a risky borrower would be willing to pay the r.h.s. of (4) to a safe borrower to accept him as a partner, the safe borrower would not be willing to accept such a side-payment, since she is willing to pay the r.h.s. of (3) to have another safe borrower as a partner rather than a risky borrower. This is the demonstration of assortative matching provided, for example, by Ghatak (1999).

Now suppose that if the group defaults, each group member loses the opportunity to borrow in the future, whose present value is $V$. Assume that $V>c$, providing members an incentive to pay the penalty $c$ when their peers default, rather than losing the opportunity to borrow in the future. Moreover, assume for simplicity that $H>c+r$, so that a borrower whose project succeeds can repay his fellow member's debt if the latter defaults. Then (1) becomes

$$
E \pi_{b b}=p_{b}^{2}(H+V-r)+p_{b}\left(1-p_{b}\right)(H+V-c-r)+p_{b}\left(1-p_{b}\right) V .
$$

The first term is the borrower's expected payoff for the case in which both borrowers' projects succeed, the second term is her expected payoff when her project succeeds but her fellow member's project fails, and the third term is her expected payoff when her own project fails, but her fellow member's project succeeds (and the fellow member repays her debt). This simplifies to

$$
E \pi_{b b}=p_{b}^{2}(c-V)+p_{b}(H+2 V-c-r) .
$$

Equation (2) becomes

$$
E \pi_{b a}=p_{b} p_{a}(H+V-r)+p_{b}\left(1-p_{a}\right)(H+V-c-r)+p_{a}\left(1-p_{b}\right) V,
$$

where the three terms correspond to the same events as before. This simplifies to

$$
E \pi_{b a}=p_{b} p_{a}(c-V)+p_{b}(H+V-c-r)+p_{a} V .
$$

Subtracting $\left(2^{\prime}\right)$ from $\left(1^{\prime}\right)$, we obtain

$$
\begin{aligned}
E \pi_{b b}-E \pi_{b a} & =\left(p_{b}-p_{a}\right)\left[p_{b}(c-V)+V\right] \\
& =\left(p_{b}-p_{a}\right)\left[V\left(1-p_{b}\right)+p_{b} c\right]>0 .
\end{aligned}
$$

As before, this is the amount that a safe borrower would have to be paid to forgo being matched with another safe borrower, and to accept a risky borrower as a fellow group member, instead.

The expected payoff of a risky borrower when matched with a safe borrower is

$$
\begin{aligned}
E \pi_{a b} & =p_{a} p_{b}(H+V-r)+p_{a}\left(1-p_{b}\right)(H+V-c-r)+p_{b}\left(1-p_{a}\right) V \\
& =p_{a} p_{b}(c-V)+p_{a}(H+V-c-r)+p_{b} V .
\end{aligned}
$$


The expected payoff of a risky borrower when matched with another risky borrower is

$$
\begin{aligned}
E \pi_{a a} & =p_{a}^{2}(H+V-r)+p_{a}\left(1-p_{a}\right)(H+V-c-r)+p_{a}\left(1-p_{a}\right) V \\
& =p_{a}^{2}(c-V)+p_{a}(H+2 V-c-r) .
\end{aligned}
$$

Subtracting (6) from (5), we obtain

$$
\begin{aligned}
E \pi_{a b}-E \pi_{a a} & =\left(p_{b}-p_{a}\right)\left[p_{a}(c-V)+V\right] \\
& =\left(p_{b}-p_{a}\right)\left[V\left(1-p_{a}\right)+p_{a} c\right]>0 .
\end{aligned}
$$

This expression gives the amount that a risky borrower would be willing to pay a safe borrower to match with him, rather than being left to match with another risky borrower. Subtracting $\left(3^{\prime}\right)$ from (7),

$$
\left(E \pi_{a b}-E \pi_{a a}\right)-\left(E \pi_{b b}-E \pi_{b a}\right)=\left(p_{b}-p_{a}\right)\left(p_{a}-p_{b}\right)(c-V) .
$$

This expression is positive if $V>c$. In this case, risky borrowers will be willing to pay more than safe borrowers to have safe borrowers as fellow members. Therefore, there would be no assortative matching if $V>c$, as claimed in the text 


\section{References}

[1] Ahlin, C. and Townsend, R.M., 2003. Using repayment data to test across models of joint liability lending. Unpublished working paper, University of Chicago.

[2] Armendáriz de Aghion, B., 1999. On the design of a credit agreement with peer monitoring. Journal of Development Economics 60, 79-104.

[3] Banerjee, A.V., Besley, T., and Guinnane, T.W., 1994. Thy neighbor's keeper: The design of a credit cooperative with theory and a test. Quarterly Journal of Economics 109, 491-515.

[4] Besley, T., and Coate, S., 1995. Group lending, repayment incentives, and social collateral. Journal of Development Economics 46, 1-18.

[5] Bratton, M., 1986. Financing smallholder production: A comparison of individual and group credit schemes in Zimbabwe. Public Administration and Development 6, 115-32.

[6] Chowdhury, P.R., 2003. Group lending: Sequential financing, lender monitoring, and joint liability. Discussion Paper 04-10, Indian Statistical Institute, Delhi.

[7] Ghatak, M., 1999. Group lending, local information, and peer selection. Journal of Development Economics 60, 27-50.

[8] Ghatak, M. and Guinnane, T.W., 1999. The economics of lending with joint liability: Theory and practice. Journal of Development Economics 60, 195-228.

[9] Godquin, M., 2002. Microfinance repayment performance in Bangladesh: How to improve the allocation of loans by MFIs? Unpublished working paper, Université Paris I Panthéon-Sorbonne.

[10] Karlan, D.S., 2005. Social connections and group banking. Unpublished working paper, Economic Growth Center, Yale University.

[11] Kritikos, A.S. and Vigenina, D., 2005. Key factors of joint-liability loan contracts: An empirical analysis. Kyklos 58, 213-38.

[12] Laffont, J.-J. and N'Guessan, T., 2000. Group lending with adverse selection. European Economic Review 44, 773-84.

[13] Montgomery, R., Bhattacharya, D., and Hulme, D., 1996. Credit for the poor in Bangladesh: The BRAC Rural Development Programme and the Government Thana Resource Development and Employment Programme. In: D. Hulme and P. Mosley, Finance Against Poverty, vol. 1. London: Routledge.

[14] Morduch, J., 1999. The microfinance promise. Journal of Economic Literature 37, 1569-1614.

[15] Paxton, J., Graham, D., and Thraen, C., 2000. Modeling group loan repayment behavior: New insights form Burkina Faso. Economic Development and Cultural Change 48, 639-55.

[16] Sharma, M. and Zeller, M., 1997. Repayment performance in group-based credit programs in Bangladesh: An empirical analysis. World Development 25, 1731-42. 
[17] Stiglitz, J., 1990. Peer monitoring and credit markets. World Bank Economic Review 4, 351-66.

[18] van Bastelaer, T. and Leather, H., 2002. Social capital and group lending: Evidence from joint liability seed loans in Zambia's southern province. Unpublished working paper, IRIS Center, University of Maryland.

[19] van Tassell, E., 1999. Group lending under asymmetric information. Journal of Development Economics 60, 3-25.

[20] Wenner, M., 1995. Group credit: A means to improve information transfer and loan repayment performance. Journal of Development Studies 32, 263-81.

[21] World Bank, 1994. Bangladesh: From stabilization to growth. Report No. 1272bD, The World Bank, Washington, DC.

[22] Wydick, B., 1999. Can social cohesion be harnessed to repair market failures? Evidence from group lending in Guatemala. Economic Journal 109, 463-75.

[23] Yunus, M., 1995. Testimony before the House [of Representatives of the U.S.] Committee on International Relations. Federal News Service, June 27.

[24] Zeller, M., 1998. Determinants of repayment performance in credit groups: The role of program design, intragroup risk pooling, and social cohesion. Economic Development and Cultural Change 46, 599-620. 